\title{
1. Contextualizing entrepreneurship in-between
}

\section{Marcela Ramírez Pasillas, Ethel Brundin and Magdalena Markowska}

\section{INTRODUCTION}

This book aims to examine entrepreneurship as a contextualized phenomenon from different theoretical and empirical perspectives. We bring forth a group of researchers with different nationalities, backgrounds and empirical contexts to shed light on how societies with alternative paths of development trigger different entrepreneurships. In this volume, the focus is on emerging economies and developing countries. We argue that distinguishing the variety of contexts for entrepreneurship as well as the context of researchers can help us to better understand the richness of entrepreneurship phenomena in the world (Welter, 2011; Zahra, 2007; Zahra et al., 2014). Entrepreneurship includes working attitudes, modes of thinking, social practices and processes (Gnan et al., 2014) that are crucial in today's societies since they foster human, organizational and economic growth. This does not, however, mean that entrepreneurship needs to be viewed and evaluated in the traditional western way. As an alternative, we conceptualize these working attitudes, modes of thinking, social practices and processes as entrepreneurship in-between. We elaborate on three aspects regarding contextualizing entrepreneurship in-between as follows: (1) misplaced, yet fertile and unexplored contexts; (2) practice and theory of contexts; and (3) driving forces for entrepreneurial practices.

\section{CONTEXTUALIZING ENTREPRENEURSHIP IN-BETWEEN MISPLACED, YET FERTILE AND UNEXPLORED CONTEXTS}

First, we take on the contextual lens of entrepreneurship in emerging economies and developing countries to make the conceptual and empirical 
contributions of this edited volume. The contextualized research reported in this book focuses its attention on the influence of geographical, social, economic and cultural contexts for entrepreneurship in emerging economies and developing countries. Traditionally, these countries have been misplaced on the periphery of a global economic order. While there is no universal, agreed-upon criterion for what makes a country developing (versus developed), different terms are used to describe countries with different paths of development. These include underdeveloped countries, under-industrialized countries, developing economies, transitional economies, emerging economies and emerging markets.

While these terms often overlap, they also make clear distinctions. These different terms relate to the definitions adopted by international organizations such as the United Nations (UN), the World Bank and the International Monetary Fund (IMF). When the gross national income per capita (GNI) or the per capita income level, the export diversification and the degree of integration into the global financial system are compared between countries, emerging economies and developing countries are referred to as less developed nations (World Bank, 2016; IMF, 2015). While these international organizations argue that these country classifications serve specific purposes (that is, lending policy, indicators of economic development and growth and so on), such classifications do not show levels of actual development in these countries. These organizations argue that the country classifications allow us to understand the level of quality of life and the availability/access to public infrastructure and services (World Bank, 2016). The aim of these classifications and policies is to raise awareness and help emerging economies and developing countries move from 'less developed' to 'more developed' or 'newly industrialized'. Thereby, less developed countries are labeled as economies in transition, developing economies, fuel-exporting countries, least developed countries and heavily indebted poor countries (UN, 2014). They can also be labeled as low-income countries, middle-income countries or upper middle-income countries (World Bank, 2016). Another classification ranges them from developing economies to emerging markets (IMF, 2015).

However, these classifications seem to consider emerging economies and developing countries in a fixed in-between position: between being developing and developed; between being in the center and at the periphery; and/or being fixed at the periphery as outliers. These definitions signal the inferior position of developing countries when compared to more advanced economies. They assume that emerging economies and developing countries aim to progress according to western models of economic development. When referring to these nations as developing countries, emerging economies, emerging markets and/or newly industrialized economies, western 
literature approaches these contexts from the point of view of what others want them to be and become. Research leaves out geographical, cultural, social, economic and political phenomena of conceptual frameworks, and field studies that are outside the so-called normality. This literature denies what these countries are or have been for long. It also seldom recognizes the countries' heritage - and the dramatic events influencing entrepreneurship (cf. Brundin and Wigren, 2013; Brundin et al., 2009; Tobias et al., 2013; Lundberg et al., 2016 for exceptions). Nevertheless, because of their ongoing in-between position, these countries provide unique and/or extreme platforms for contextualizing entrepreneurship.

Entrepreneurship confronts dramatic circumstances and lack of resources to pursue opportunities in emerging economies and developing countries (Reynolds, 2012; Bruton et al., 2013). In its original meaning, entrepreneurship is linked to out-of-the-box thinking to act on opportunities in combination with scarce resources and/or in tight circumstances (cf. Fletcher, 2006; Bruton et al., 2010). This makes entrepreneurship in these contexts extra relevant. In societies where higher levels of uncertainty exist - due to poverty, increased growth in populations, lack of access to education and medical health programs, famines and epidemics, unemployment, gender inequality, government corruption, natural catastrophes and organized crime -entrepreneurship materializes by means of activities, practices and processes that differ from those in other countries where there is institutional certainty.

When considering the historical, temporal, institutional, geographical, spatial and social contexts, emerging economies and developing countries embody individuals, families and networks with opportunities for venture creation and renewal in as much as these contexts set boundaries for their actions (cf. Welter and Smallbone, 2008; Brundin et al., 2008). As a result, entrepreneurship in-between offers us an alternative perspective for placing geographical contexts that have traditionally been misplaced in our understanding and conceptualization of practices, and thereby build on or expand theories on entrepreneurship.

The research of entrepreneurship in-between covered in this book addresses geographical contexts traditionally classified as emerging economies and developing countries. Table 1.1 shows that the classification of a country differs depending on the source and how the concept of an emerging economy and a developing country is measured. It also shows that the label of being an emerging and developing country or an advanced economy is flexible and can change in a short time period. For instance, the World Bank revises its classification year by year and the IMF changes its classification when something in the outcome of the measurement becomes 'overwhelmingly' different. So, for example, in 2016 Greece is still an advanced 


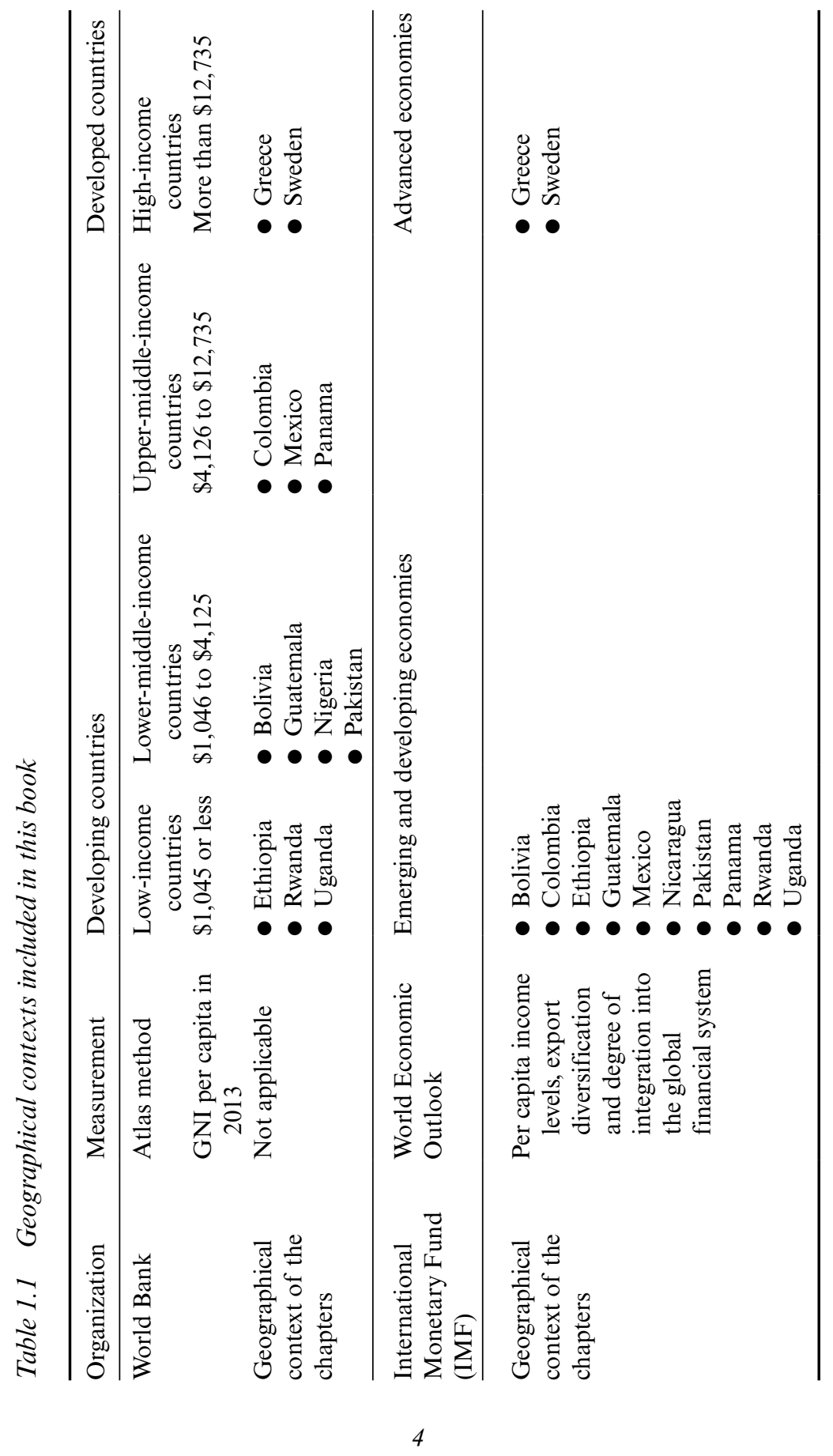


economy according to the IMF, but is considered an emerging economy by other organizations (Sizemore, 2016). It is the first country to be degraded from a developed country to an emerging market (Dunkley, 2016).

From Table 1.1 we can also establish that the authors of this book cover geographical contexts from five continents with countries belonging to emerging economies and/or developing countries:

- Africa (Ethiopia, Rwanda and Uganda)

- Asia (Pakistan)

- Europe (Greece)

- North America (Guatemala, Mexico, Nicaragua and Panama) and

- South America (Bolivia and Colombia).

We also include other developed countries as an exception in two contributions where the focus is on immigrant entrepreneurship (that is, Greece and Sweden).

Implicitly, we also take a stand against the so-called definitions of countries driven by a center and periphery theory, which is subdued to a political global economic order (Galtung, 1971). The center and periphery theory indicates that development problems within a center/periphery global system serve the interests of central forces in the global world order. While developed countries occupy positions in the center, the rest are placed at the periphery (Naustdalslid, 1977). A sustainable developed world requires people, resources, experiences and histories available in every society. To us, this implies that all countries enter the global system not as differentiated units, but as equal units that can create socioeconomic development when recognizing, for instance, the role and relevance of contextualizing entrepreneurship in-between.

\section{CONTEXTUALIZING ENTREPRENEURSHIP IN- BETWEEN PRACTICE AND THEORY OF CONTEXTS}

We identify entrepreneurship as a phenomenon anchored in-between the practice and theory of contexts in emerging economies and developing countries. Following Steyaert (2005: 8), we propose that contextualizing entrepreneurship in-between builds upon the practice and theory of contexts occurring in an 'open space and open time, an in-between that thrives on tensions and dynamics, a rhizome, an unstable network.' Entrepreneurship is thereby acknowledged as a contextually driven phenomenon of societies (Steyaert and Katz, 2004). Yet, dealing with a contextually driven phenomenon of societies properly calls for a review of 
ontological and epistemological considerations vis-à-vis the practice and theory of contexts. We address four considerations here.

First, we question the objective nature of a researcher's approach to ontology. In our perspective, the researcher is not an external actor (that is, an objective outsider) to the phenomenon being investigated: the researcher's background matters in contextualizing entrepreneurship research inbetween in emerging economies and developing countries (that is, country of origin, family, class, gender, education and prior experiences). Chia and Holt (2009: 23) refer to this as 'internalized predisposition' that individuals develop through socialization processes which provides researchers the necessary ability to conduct research. Johannisson (2014: 229) calls it 'being close, being there,' and invites the practice framework (cf. also Johannisson, 2011). In our perspective, entrepreneurship in-between becomes the practice of making-do (Sarasvathy, 2001) that allows researchers to generate more detailed observations of societies (cf. Chia and Holt, 2009). Making use of the particular background of a researcher allows us to un-westernize research in a variety of ways. To investigate entrepreneurial practices in emerging economies and developing countries, we encourage the identification of places where knowledge on entrepreneurship in-between can be produced or co-produced in line with the researcher's background. The researchers can thus adopt three different approaches to investigate entrepreneurship in-between: a common sense approach, a symbolic approach and a habitual approach.

They can opt for a common sense approach to identify entrepreneurial practices which are part of the obvious in their respective societies. Such an approach is anchored in entrepreneurial practices embedded in the tacit knowledge of everyday life. It is featured by the continuous adaptation to a number of circumstances. Examples of this approach are: entrepreneurs selling drinks outside a football stadium if it is warm, or selling umbrellas and raincoats if it starts raining or entrepreneurs selling tacos and coffee in their food stands in the morning, or soups and warm drinks at night. Researchers can also take on a symbolic approach to bring in entrepreneurial practices, which constitutes a common representation of their societies. Symbolic representations of entrepreneurial practices manifest in signs, figures, images, photos or emblems featuring societies. Examples of this approach are: the use of religious symbols in jewelry that is revamped into cool products beyond jewelry by entrepreneurs or the use of emblems in nail art designs by entrepreneurs. Finally, they can investigate phenomena that they traditionally leave out since they are not part of western literature by adopting a habitual approach. A habitual approach includes focusing on entrepreneurial practices that are constantly and regularly done as part of everyday life in their societies: university students developing temporary 
enterprising ventures to finance their studies; wives becoming part-time entrepreneurs contributing to family economies.

When adopting any of the proposed approaches to study entrepreneurship in-between, researchers have the opportunity to incorporate 'materially mediated arrays of human activity centrally organized around shared practical understandings' (in Schatzki et al. 2001: 2). Thus, the valuable link between practice and theory with regard to the ontological approach of researchers and their research can help us study entrepreneurship in-between in a better way.

Second, with regard to epistemological considerations for investigating contexts, our perspective invites researchers to make more powerful use of the ways in which they become familiar with the context of study. To address practices, issues of the familiarity of the context need a deeper look at the research design and methods (Johannisson, 2014). In this regard, Chia and Rasche (2010) emphasize the importance of dwelling worldviews, since individuals grow and re-grow surrounded by or embedded in practices that are a product of their specific backgrounds: they unconsciously internalize, take-in and become familiar with practices. Examples of such 'situatedness' of practice constitute the in-between situations which researchers tap into by using familiar surroundings in the study of entrepreneurship in-between. These situations emerge from practices close to researchers and provided by their own nuclear family, extended family, friends, students, professors, co-workers, neighbors and/ or acquaintances. Such situatedness of practices allows researchers to be 'intimately immersed and inextricably intertwined with their surroundings in all its complex interrelatedness' (Chia and Rasche, 2010: 38). This of course implies a careful methodological design to assure the quality of research.

Third, also with regard to the epistemological considerations of studying contexts, we highlight the importance of the diversity, nuances and multiplicity of facets of relevant but unexplored contexts of societies in emerging economies and developing countries (cf. Härtel and O'Connor, 2014; Welter, 2011; Zahra, 2007). Contexts thus include the where, who, how, why and when of entrepreneurial practices that occur in a society (Welter, 2011; Zahra et al., 2014). In this book 'where' refers to the multiplicity of countries in which entrepreneurship occurs; but it also goes beyond the countries. The 'where' dimension includes the business, the social, the spatial or the institutional settings. The studies move within and beyond country, region and locality. They are anchored in society through carnivals and festivities, fairs, tradeshows, streets, homes, offices, market places, policy documents, universities, villages as well as ship canals. 'Who' comprises the individual (male and female), the family, academics, 
policymakers and activists and networks. The 'how' links to the institutional context shaping and reshaping a venture: the process, the practices and the activities with the 'why' allowing us to understand the motives and the needs triggering new venture creation or venture renewal. 'When' allows us to understand changes in the multiplicity of temporal contexts and their impact on the types and processes of venture creation (Zahra et al., 2014). Thus, history, time and space are central elements in contextualizing entrepreneurship research in-between.

Fourth, with regard to epistemological considerations, contextualizing entrepreneurship in-between as a perspective consists of embracing, connecting, repositioning concepts and theories of entrepreneurship and contexts. Embracing entrepreneurship in-between means that a researcher identifies a phenomenon that is not considered entrepreneurial - or one that is being left out of traditional western research by following our suggested approaches (that is, common sense, symbolic or habitual). The identification of a new phenomenon creates conceptual opportunities relevant for entrepreneurship in-between. When uncertainty and dramatic events co-exist in emerging economies and developing countries, apparently mundane decisions, activities and processes become entrepreneurial (for example, Rehn and Taalas, 2004). When uncertainty and specific cultural features meet (that is, losing face, changing religion), entrepreneurial processes might be triggered. When certainty, love and identity-search coexist, entrepreneurial intentions can be explored (that is, getting married, becoming a mother, divorcing or becoming widowed).

Connecting concepts and theories of entrepreneurship and contexts implies that a researcher aims for variation, intensity and connected attempts (Steyaert, 2005). This includes linking new phenomena with existing research and clearly distinguishing theoretical contributions. The aim can be to either create new theory (Eisenhardt and Graebner, 2007; Gioia and Pitre, 1990) or to create new concepts that help us develop existing theories (Whetten, 1989). Repositioning concepts and theories of entrepreneurship and contexts includes moving existing pre-understandings or conceptualizations to fully account for the phenomena being investigated (for example, Welter and Smallbone, 2008). Repositioning promotes a more ambitious research agenda since it aims to influence dominant views of communities of scholars.

The research reported in this book aims to develop conceptual frameworks that contextualize entrepreneurship anchored in-between practice and theory. The authors link contextual practices to existing theories within the field of entrepreneurship. They recognize that contexts allow them to better understand where, who, how, why and when entrepreneurship in-between happens in society. They also develop critical thinking 
literature reviews which reposition western perspectives and create openings for contextualizing entrepreneurship in emerging economies and developing countries. Thereof, the reported research is grounded in the perspective of contextualizing entrepreneurship primarily within social and human sciences. It draws on and aims to contribute to disciplines such as business administration, sociology and economic geography. As a result, the chapters generate contexts for entrepreneurship in-between research in alternative contexts (cf. Rehn and Taalas, 2004; Hjorth et al., 2008 for contextualizing entrepreneurship examples). Finally, the chapters also exemplify how research contributes to the creation of society by raising awareness of alternative entrepreneurship (that is, for society).

\section{CONTEXTUALIZING ENTREPRENEURSHIP IN-BETWEEN: THREE TYPES OF DRIVING FORCE FOR ENTREPRENEURIAL PRACTICE}

In the preparations and compilation of this edited volume it became clear that contributions by different authors contextualize entrepreneurship inbetween by means of three types of driving force for entrepreneurial practice. These originate from top-down, bottom-up or a combination of the two, the hybrid. For the top-down type of driving force, institutions shaped by laws and constitutions, or organizational and cultural frameworks (North, 1990), define the dominant context that establishes or attempts to regulate entrepreneurship. Within the bottom-up type of driving force, entrepreneurial practices result from actions anchored in individual and/ or collective needs, and also in the lack of available resources in constraint contexts (cf. Hahn, 2012). Entrepreneurs find ways to steer the institutional framework. The hybrid type of driving force, results from entrepreneurial practices where the bottom-up driving forces are combined with the top-down types, letting an entrepreneur make use of, or benefit from, the institutional framework (Welter, 2011).

We believe that these three types of driving force are relevant for the contexts wherein they exist: they characterize the contexts in their own right, and this allows us to embrace new phenomena and connect or reposition current understandings and conceptualizations in the field of entrepreneurship. This is also the way we have structured this volume.

In Part I some of the initial chapters include the top-down driving forces where the authors refer to a set of institutional initiatives that facilitate or restrain entrepreneurial practices. The bottom-up driving forces are the focus of Part II, where entrepreneurs, couples, families, networks and/ or communities struggle against the odds to create openings for their 
entrepreneurial practices. Finally, the hybrid driving forces in Part III gather those chapters where entrepreneurs and researchers combine and interact with different types of driving forces; these are problematized and discussed.

\section{Part I Contextualizing the Top-Down Driving Forces for Entrepreneurial Practices}

Part I provides input from authors who show how the government or other institutional forces or circumstances set the scene for entrepreneurial activities. This part consists of seven chapters contextualizing institutional forces in Ethiopia, Rwanda, Mexico and Panama/Mexico/Nicaragua. As shall be seen, these forces do not always provide the optimal circumstances for entrepreneurship activities, and the authors also make us rethink takenfor-granted notions about entrepreneurship. Hussien Yimam in Chapter 2 investigates how the political economy of Ethiopia has had an impact on indigenous ethnic entrepreneurship. He shows how the regimes shape and reshape the development of indigenous ethnic entrepreneurs in two groups, the Afar and the Gurage, during the regime of Emperor Haile Selassie I, the Derg Regime and the Ethiopian People's Revolutionary regime, spanning over 85 years. Each regime creates its own conditions for indigenous groups, and the author illustrates how politics plays a significant role in the business landscape among ethnic entrepreneurs. In Chapter 3 , the same author poses the question: 'who is really an ethnic minority?' He argues that western discourse on ethnic entrepreneurship does not apply to the Ethiopian context. Rather, by admitting to the influence of institutionalized social, cultural, political and economic processes, Hussien offers a novel view on an ethnic minority when he conceptualizes four groups of power minorities.

Jean Bosco Shema and Samuel Mutarindwa in Chapter 4 investigate the institutional support for women entrepreneurs as formulated in policy documents by the government of Rwanda. Regardless of policy, women stereotypes remain and, despite the progress made in institutionalization of gender initiatives, the authors argue that policymakers need to address ways of working around these stereotypes if they take their task to increase women's participation in venture creation seriously. In Chapter 5, the topic is the same, but the context is Ethiopia when Hailemickael Deres Mekonnen and Joaquín Cestino investigate the country's institutional barriers for women entrepreneurs through a literature review. They address the complex interplay of formal and informal institutional contexts and show how these intertwine and interact. The authors argue that, despite new laws and policies, policymakers have not been able to overcome 
traditional norms and values underlying the institutional context. There is a need to find ways out of this dilemma where institutional discourse is followed in practice and not only on paper.

Chapter 6 by Edmundo Ramírez Pasillas and Hans Lundberg exemplifies how institutional evangelizing impacts contextual conditions for micro- and medium-sized businesses in Mexico. The authors illustrate the introduction of entrepreneurial practices in the religious practice of diezmo and informal contract commissions that entrepreneurs are subject to from government officers and professional acquaintances. The authors show the role of informal Mexican practices to promote and hinder entrepreneurship. Chapter 7 by Fernando Sandoval-Arzaga, David S. Xotlanihua González, Geraldina Silveyra and María Fonseca-Paredes embraces universities as a relevant institutional context for new venture creation of students from family businesses at the Tecnologico de Monterrey in Mexico. According to the authors, universities typically promote entrepreneurship through education, whereas the Tecnologico de Monterrey combines the use of education, teachers, infrastructure and family networks to promote the creation of ventures. As a result of an analysis of three start-ups, the authors offer a model of triggers for new venture creation through the university curriculum.

Hans Lundberg turns to Panama, Nicaragua and Mexico in Chapter 8 for an analysis of the institutional forces in play when shipbuilders communicate about mega-ship canal projects. In his analysis, Lundberg narrates an 'entrepreneurial process in becoming' through the example of 'seriousness,' making a temporal shift from what is already being done to what may be. The author embraces seriousness as a relevant entrepreneurial phenomenon, and thus offers some insights for entrepreneurs involved in mega- and meso-scale entrepreneurship projects where they have to address various contextual conditions.

\section{Part II Contextualizing Bottom-Up Driving Forces for Entrepreneurial Practices}

Part II highlights the roles of entrepreneurs, families, networks and communities in the activities and priorities to be pursued in business and/ or communities in Pakistan, Ethiopia, Bolivia and Rwanda. Khizran Zehra in Chapter 9 connects the concept of jugaar (or jugaad) to entrepreneurial resourcefulness. While jugaar refers to creative problem solving in situations characterized by resource scarcity commonly prevalent in Pakistan and India, entrepreneurial resourcefulness addresses the capacity building of entrepreneurs to cope with institutional constraints. The author exemplifies the theoretical link between jugaar and entrepreneurial 
resourcefulness with three Pakistani cases showing the creation of innovative solutions for promoting inclusive entrepreneurship and sustainability at the bottom of the pyramid.

In Chapter 10, Yaschilal Shitaye Anely focuses on the Gurage ethnic group in Ethiopia to contextualize entrepreneurial Ekub networks. The author studies how the Gurage people are pushed by their families to start businesses outside their communities. The families are in poor financial situations and expect their children to improve their overall situation. Entrepreneurs create micro-businesses, save money and eventually join an Ekub network which provides a context for financing the expansion of future ventures when there is no support from financial institutions.

Nadia Arshad in Chapter 11 investigates how social entrepreneurs use crowdfunding in Pakistan to raise the living standards of people below the poverty line. The author presents the case of a Pakistani-based notfor-profit crowdfunding platform financing micro-entrepreneurs. To bring about social change, this venture influences the social context, namely people's behavior. Micro-entrepreneurs pay back the funds received from the NGO, in turn the NGO supports other micro-entrepreneurs. Arshad contributes to entrepreneurship literature by repositioning the role of crowdfunding in alleviating poverty and bringing about social change.

In Chapter 12, Yikaalo Welu Kidanemariam focuses on the varied roles of human capital with regard to formal and informal knowledge and skills as a basic antecedent for new venture creation. Two Ethiopian entrepreneurial cases are presented in this chapter. The first case illustrates the importance of migration in building a knowledge base in a foreign country, which is beneficial for starting a venture in the home country. The second case shows how prior experience in a family-owned mechanical workshop combined with formal education was used to create a first venture. According to the author, venture creation results from the individual process of 'making-do'. Demeke Chimdessa Gutu and Jebessa Teshome Bayissa's Chapter 13 explores the opportunity-creation process resulting from social embeddedness. The authors present two cases in Ethiopia which highlight the importance of artisanal skills to create and recreate opportunities that generate new products and support the family economy. While the entrepreneurial learning theory emphasizes the role of knowledge and technology, this case repositions artisanal skills as the originator of entrepreneurial activities that aim to conserve practices, refresh products and sustain communities.

Chapter 14 by Maria José Parada and Alexandra Dawson examines the influence of copreneurs' practices in shaping the business context while being affected by their geographical and institutional contexts. The authors present the case of a tourist agency owned by an entrepreneurial 
couple that provides overseas services for the first time in Bolivia. These copreneurs act as institutional entrepreneurs changing the traveling culture of this developing country. They shape customer behavior and the overall tourism business. This case allows us to reposition our understanding of copreneurship as a relevant phenomenon influencing and changing institutional and business contexts.

Pierre Sindambiwe in Chapter 15 investigates the interplay between the territorial context and a family business located therein by conducting a literature review. The author discusses how family businesses build a territorial identity to connect with the population of a given region. The interplay between the region and the family business also influences business social responsibility activities. Thus, Rwandan family businesses take advantage of available regional opportunities and exploit resources while being useful to the local community.

Chapter 16 by Ermias Werkilul Asfaw explores entrepreneurship in family businesses in Ethiopia. The author argues that because families are embedded in a social system of relations, they engage more often in recognizing entrepreneurial opportunities and acting upon them. He interviews Ethiopian managers of family businesses to map relevant attitudes and activities supporting entrepreneurship. The author reports that these managers share a sense of adventure and strong self-confidence due to continuous encouragement by their families for starting companies or introducing new products. The families provide a suitable social context for creating a business context in an institutionally uncertain context.

\section{Part III Contextualizing Hybrid Driving Forces for Entrepreneurial Practices}

Part III consists of seven contributions that present contexts where hybrid driving forces are at play in Uganda, Colombia, Rwanda, Guatemala, Greece, Ethiopia and Sweden. Chapter 17 by Peter Rosa and Waswa Balunywa shows the complexity of contextualizing entrepreneurship in-between different driving forces in Uganda. The authors argue against the oversimplification of high entrepreneurship rates as a symptom of poverty. The complexity of the Ugandan entrepreneurship ecosystem includes actors and regulatory frameworks originating apparent non-productive entrepreneurship in western eyes. Yet this so called 'non-productive' ecosystem is surprisingly creating value in Uganda and still hoping for an upgrade of institutions and infrastructure.

Erika Arévalo's Chapter 18 connects the Colombian city of Barranquilla's carnival with societal entrepreneurship by examining how the carnival makes it possible to realize the entrepreneurial craftwork of 
artists and artisans, which is rooted in the city's identity. Economic gains from the carnival are not as important as the preservation and promotion of traditions. Thus, culture fosters entrepreneurial craftwork as much as it limits it, since new techniques and technologies are not admitted. An understanding of entrepreneurship is expanded from a conceptualization anchored in the new to an entrepreneurship that exists in the conservation of traditions.

In Chapter 19, Samuel Kamugisha embraces a relevant phenomenon in the entrepreneurship field - the very low survival rate of new firms in Rwanda. Focusing on the interplay of institutional and social contexts, the author suggests that the inefficiency and loopholes in policies and laws limit the chances of survival of businesses that lack knowledge about loopholes and have poor networks. Further, he notes that problems with accessing finance also reduce the probability of a firm's survival. Next, Marcos Vega Solano and Alan Discua Cruz in Chapter 20 present a case of a successful and growing Guatemalan family-run coffee farm that dared to be different by positioning its product while facing an expired international agreement. The company found ways to create a sustainable business model allowing the growth and prosperity of the family business. The authors explore how the expiration of the agreement paved the way for entrepreneurial action, and how enterprising individuals created value in a context that normally was not considered very entrepreneurial.

Diogenis Baboukardos and Naveed Akhter's Chapter 21 is a unique point of departure, since their focus, Greece, used to be a developed context but has become a developing one after a major financial crisis. Using quantitative data spanning the pre-phase, the peak of the financial crisis and its aftermath, the authors speculate on why non-family firms performed better before the crisis than family firms. However, during the crisis, family firms' financial performance did not dip as much as that of non-family firms. This indicates that family firms are better at withstanding institutional and financial pressures, pointing to an alternative space where entrepreneurial activities occur.

Next, Asres Abitie Kebede in Chapter 22 carries out a literature review of immigrant entrepreneurship and challenges the idea of mixed embeddedness, with its emphasis on host setting (that is, laws, norms, rules, behaviors and so on). The author focuses on the role that the host country and its legislation plays in enabling or disabling immigrants' entrepreneurial actions. He notes that immigrant entrepreneurs often start companies in sectors different from their professional and educational qualifications, which constitutes a serious problem of occupational mismatch. Consequently, he stresses the challenge for immigrant entrepreneurs to build and maintain strong and salient identities throughout the process. 
Chapter 23 by Quang Evansluong challenges the view that one size fits all which is dominant in immigrant entrepreneurship research. His literature review of immigrant entrepreneurship in Sweden identifies a double challenge - oftentimes concurrent structural and ethnic discrimination. He also argues that immigrant entrepreneurs can no longer be researched as a homogenous group. Instead he proposes that every immigrant group should be considered through the cultural, social and institutional contexts that fuel their sources of uniqueness. Contextualizing immigrant entrepreneurship helps us understand why immigrant entrepreneurs do what they do, in the ways they do it, and why they do not all do it in the same way.

Finally, Rodrigo Basco's epilogue, Chapter 24, helps us make sense of the contributions in this book by developing a framework to contextualize the phenomenon of entrepreneurship in-between. Basco depicts the influences of the macro-context and the meso-context on the entrepreneurial practices. The influences of these contexts are, however, anchored in a spatial dimension and a time dimension needed to grasp the multiplicity and multifaceted nature of entrepreneurship in-between.

In sum, each chapter enables us to embrace a new phenomenon, to connect with or reposition entrepreneurship in-between emerging economies and developing countries. They highlight the possibilities that are generated when unexplored contexts are brought to light. Clearly the in-between has profound, complex and diverse implications for the field of entrepreneurship. The chapters in this book offer a lens on the in-between that has traditionally not been addressed by entrepreneurship research. Our hope is that this book stimulates you to conduct research that acknowledges the importance of entrepreneurship in-between.

\section{REFERENCES}

Brundin, E. and Wigren, C. (2013). Where the two logics of institutional theory and entrepreneurship merge: are family business owners caught in the past or stuck in the future? South African Journal of Economic and Management Sciences, 16: 452-467.

Brundin, E., Wigren, C., Isaacs, E. and Visser, K. (2009). Ethnic entrepreneurship in a multicultural context: regional development and the unintended lock-in effects. International Journal of Entrepreneurship and Small Business, 8: 449-472.

Brundin, E., Wigren, C., Friedrich, C., Isaacs, E. and Visser, K. (2008). Triple helix networks in a multi-cultural context: triggers and barriers for fostering growth and sustainability. Journal of Developmental Entrepreneurship, 13: 77-98.

Bruton, G.D., Ahlstrom, D. and Li, H. (2010). Institutional theory and entrepreneurship: where are we now and where do we need to move in the future? Entrepreneurship Theory and Practice, 34: 421-440. 
Bruton, G.D., Ketchen Jr., D.J. and Ireland, R.D. (2013). Entrepreneurship as a solution to poverty. Journal of Business Venturing, 28: 683-689.

Chia, R.C.H. and Holt, R. (2009). Strategy without Design: The Silent Efficacy of Indirect Action, Cambridge: Cambridge University Press.

Chia, R. and Rasche, A. (2010). Epistemological alternatives for research strategy as practice: building and dwelling worldviews. In: Golsorkhi, D., Seidl, D., Rouleau, L. and Vaara, E. (eds), The Cambridge Handbook of Strategy as Practice. Cambridge: Cambridge University Press, pp. 34 46.

Dunkley, J. (2016). Greece becomes first developed country to be downgraded to emerging-market status. The Independent. Retrieved from: http://www.independ ent.co.uk/news/business/news/greece-becomes-first-developed-country-to-be-do wngraded-to-emerging-market-status-8655730.html (May 6).

Eisenhardt, K.M. and Graebner, M.E. (2007). Theory building from cases: opportunities and challenges. Academy of Management Journal, 50: 25-32.

Fletcher, D.E. (2006). Entrepreneurial processes and the social construction of opportunity. Entrepreneurship and Regional Development, 18: 421-440.

Galtung, J. (1971). A structural theory of imperialism. Journal of Peace Research, 8: $81-117$.

Gioia, D.A. and Pitre, E. (1990). Multiparadigm perspectives on theory building. Academy of Management Review, 15: 584-602.

Gnan, L., Lundberg, H., Sognini, L. and Pellegrini, M. (2014). Advancing European Entrepreneurship Research: Entrepreneurship as a Working Attitude, a Mode of Thinking and Everyday Practice. Charlotte, NC: Information Age Publishing.

Hahn, R. (2012). Inclusive business, human rights and the dignity of the poor: a glance beyond economic impacts of adapted business models. Business Ethics: A European Review, 21: 47-63.

Härtel, C.E.J. and O'Connors, J.M. (2014). Contextualizing research: putting context back into organizational behavior research. Journal of Management and Organization, 20: 417-422.

Hjorth, D., Jones, C. and Gartner, W.B. (2008). Introduction for 'recreating/ recontextualising entrepreneurship.' Scandinavian Journal of Management, 24: $81-84$.

International Monetary Fund (2015). Q. How does the WEO categorize advanced versus emerging market and developing economies? www.imf.org/external/pubs/ $\mathrm{ft} /$ weo/faq.htm\#q4b. Downloaded July 27, 2015.

Johannisson, B. (2011). Towards a practice theory of entrepreneuring. Small Business Economics, 36: 135-150.

Johannisson, B. (2014). The practice approach and interactive research in entrepreneurship and small-scale venturing. In: Carsrud, A. and Brännback, M. (eds), Handbook of Research Methods and Applications in Entrepreneurship and Small Business. Cheltenham, UK and Northampton, MA, USA: Edward Elgar Publishing, pp. 228-258.

Lundberg, H., Ramírez Pasillas, M. and Högberg, A. (2016). Towards a Conceptual Model for Heritagepreneurship and Regional Development. Springer Proceedings in Business and Economics: Springer.

Naustdalslid, J. (1977). A multi-level approach to the study of center-periphery systems and socio-economic change. Journal of Peace Research, 14: 203-222.

North, D.C. (1990). Institutions, Institutional Change and Economic Performance. Cambridge: Cambridge University Press. 
Rehn, A. and Taalas, S. (2004). 'Znakomstva i svyazi' (acquaintances and connections): blat, the Soviet Union, and mundane entrepreneurship. Entrepreneurship and Regional Development: An International Journal, 16: 235-250.

Reynolds, P.D. (2012). Entrepreneurship in developing economies: the bottom billions and business creation, Foundations and Trends in Entrepreneurship, 8 (3), 141-277.

Sarasvathy, S.D. (2001). Causation and effectuation: toward a theoretical shift from economic inevitability to entrepreneurial contingency. Academy of Management Review, 26: 243-63.

Schatzki, T.R., Knorr Cetina, K. and Savigny, E.V. (eds) (2001). The Practice Turn in Contemporary Theory. New York: Routledge.

Sizemore, C. (2016). Greece downgraded to 'emerging market,' but will it ever emerge? Forbes. Retrieved from: http://www.forbes.com/sites/moneybuilder/2013/06/20/greece-downgraded-to-emerging-market-but-will-it-ever-em erge/\#3c01fc6c1eZa4 (May 6).

Steyaert, C. (2005). Entrepreneurship: in between what? On the 'frontier' as a discourse of entrepreneurship research. International Journal of Entrepreneurship and Small Business, 2: 2-16.

Steyaert, C. and Katz, J. (2004). Reclaiming the space of entrepreneurship in society: geographical, discursive and social dimensions. Entrepreneurship and Regional Development: An International Journal, 16: 179-196.

Tobias, J.M., Mair, J. and Barbosa-Leiker, C. (2013). Toward a theory of transformative entrepreneuring: poverty reduction and conflict resolution in Rwanda's entrepreneurial coffee sector. Journal of Business Venturing, 28: 728-742.

United Nations (2014). Country classification: data sources, country classifications and aggregation methodology. Retrived from: http://www.un.org/ en/development/desa/policy/wesp/wesp_current/2014wesp_country_classificat ion.pdf (June 10, 2016).

Welter, F. (2011). Contextualizing entrepreneurship: conceptual challenges and ways forward. Entrepreneurship Theory and Practice, 35: 165-184.

Welter, F. and Smallbone, D. (2008). Women's entrepreneurship from an institutional perspective: the case of Uzbekistan. International Entrepreneurship and Management Journal, 4: 505-520.

Whetten, D. (1989). What constitutes a theoretical contribution? Academy of Management Review, 14, 490-495.

World Bank (2016). Updated income classifications: http://data.worldbank.org/ news/2016-country-classifications. Downloaded June 9, 2016.

Zahra, S. (2007). Contextualising theory building in entrepreneurship research. Journal of Business Venturing, 22: 443-452.

Zahra, S., Wright, M. and Abdelgawad, S.G. (2014). Contextualization and the advancement of entrepreneurship research. International Small Business Journal, 20: $479-500$. 
Marcela Ramírez Pasillas, Ethel Brundin, and Magdalena Markowska - 9781785367533 Downloaded from PubFactory at $04 / 26 / 2023$ 12:35:45PM via free access 